$5^{\text {th }}$ International Conference on

Innovation in Science and Technology

ISTCONF

Barcelona - Spain

7 - 9 December, 2018

\title{
INNOVATIVE ANAMMOX ELECTRO-BIOREACTOR TREATING MUNICIPAL WASTEWATER AT LOW TEMPERATURE
}

\author{
Abdelmajeed Adam \& Maria Elektorowicz \\ Department of Building Civil \& Environmental Engineering (BCEE), Concordia \\ University, \\ 1455 De Maisonneuve Blvd. West, Montréal, Québec, Canada, H3G 1M8 \\ Corresponding Author Email: Abdelmajeed.adam@mail.mcgill.ca
}

\section{ABSTRACT}

The anammox (anaerobic ammonium oxidation) process is a promising nitrogen removal technique alternative to conventional nitrification-denitrification, which directly oxidizes ammonium to diatomic nitrogen gas using nitrite as the electron acceptor without oxygen and external carbon supplies, and hence achieving high energy-saving potential. Yet, the implementation of anammox-related process is still limited to side-stream treatment of municipal sewage mainly due to lower operating temperatures and nitrogen concentrations of mainstream conditions. In this work, a novel lab-scale anammox electro-bioreactor was constructed to examine whether the anammox biomass would preserve activity at low temperature, in addition to investigate the potential application of mainstream anammox to treat a synthetic domestic wastewater containing $34 \mathrm{mg} / \mathrm{L}$ ammonium. A synthetic solution, consisting mainly of sodium nitrite and ammonium sulfate was used to feed the anammox reactor in the 
$5^{\text {th }}$ International Conference on

Innovation in Science and Technology

\section{ISTCONF}

Barcelona - Spain

7 - 9 December, 2018

26 ratio $1: 1$ at HRT of 1 day. After 4 months of stable operation, temperature was a stepwise

27 decreased by $1^{\circ} \mathrm{C}$ each $4-5$ days, and afterwards heating device was disconnected maintaining

28 sludge temperature at $14 \pm 2{ }^{\circ} \mathrm{C}$. Results showed that the novel reactor achieved simultaneous

29 removal of nitrate and ammonia by over $80 \%$ and $83 \%$, respectively. The anammox electro-

30 bioreactor successfully preserved adequate activity as a result of biomass adaptation to low

31 temperature and substrate conditions. Furthermore, microbial community analysis by 16S rRNA

32 analysis also proved the presence of the anammox bacteria at low temperature, while the

33 abundance of anammox cells was severely affected by organic carbon inputs in the synthetic 34 influent.

Keywords: anammox electro-assisted bioreactor; low temperature; low-strength ammonium; 38 mainstream anammox process; sustainable technology 